Heggie's study adds weight to critical voices who question the 'legacy' claims of longerterm health benefits of the Olympics for the local community in East London.

\title{
Ina Zweiniger-Bargielowska
}

University of Illinois

\author{
Vladimir Jankovic, Confronting the Climate: British Airs and the Making of \\ Environmental Medicine, Palgrave Studies in the History of Science and Technology \\ (New York: Palgrave Macmillan, 2010), pp. x + 227, \$80.00, hardback, ISBN: \\ 978-0-2301-0475-4.
}

In this creatively structured and dense but concise book, Vladimir Jankovic locates today's focus on environmental risk in the fear of exposure that gradually but powerfully gripped British society during the eighteenth century. Jankovic shows how the affluence of the middle and upper classes made possible both unprecedented levels of material comfort and unprecedented possibilities for cleanliness, ventilation and disease prevention. The arena in which all of this took place was a mundane one: the household. Domestic space, Jankovic observes, 'has so far received only a marginal treatment in environmental history, and still less in the history of science and medicine' (p. 41). Jankovic shows us that eighteenth-century Britain is an important setting in which to begin addressing this historiographical lacuna.

The fundamental lesson of Confronting the Climate is that during the eighteenth century, affluent Britons came to see their bodies as inherently vulnerable and in need of vigilant care. The possibility of disease, rather than disease itself, dominated the privileged social classes. The result was an increasing fear of exposure, not to harsh English weather, but to everyday dangers found within the home itself.

The opening chapter ('Exposed and Vulnerable') introduces models of the body popular in eighteenth-century scientific and medical circles. These included the hydraulic body acutely affected by air and pressure changes and the nervous body defined by its 'sensibilities' to environmental stimuli. The end result was an environmentalist approach to the body in which anything in the environment had the potential to affect health and disease. This body would come to require increasingly vigilant protection from any and all environmental hazards: "whether as a finely tuned hydraulic machine or a strung-up network of nerves, eighteenth-century physicians represented the body as an entity under constant pressure to yield its health to outside powers' (p. 39).

Each of four subsequent chapters explores an intervention intended to protect middleclass Britons from the dangers of exposure: domestic architecture, domestic appliances, clothing and health travel.

In chapter 2 ('Cursed by Comfort'), Jankovic observes that 'the urban home was increasingly papered, carpeted and curtained, features that lessened the airflow and increased the absorption of odors by books, pictures, collectibles, statuettes and sundry trinkets' (p. 61). But comfort had its consequences: such well-appointed homes required attentive 'surveillance and management', increasingly by servants. Failure to keep up meant that the home could quickly harbour 'instant pathological potential' (p. 61). By the late eighteenth century, physicians such as Jonas Hanway implicated poor air quality in a range of ailments, positioning health as a commodity that was constantly under threat from the very surroundings that were supposed to offer protection. 
However, much like today, eighteenth-century innovators stepped into the marketplace, offering devices designed to improve ventilation. Chapter 3 ('Artificial Airs') highlights some of these technologies. Readers may recognise their own modern window fans in Thomas Tidd's 'Aeolus', introduced in the early 1750s and named after the ancient god of wind. Such devices were popular among royalty and other élites: 'ventilation stirred an enormous public interest and soon lived to become an emblem of enlightened rationality and domestic ideals of comfort' (p. 69). Jankovic argues that such interest indicated a re-definition of health and disease that only made sense when the body was analysed in relation to its immediate surroundings.

Clothing may seem an unlikely candidate for inclusion in a book ostensibly about air, but chapter 4 ('Intimate Climates') shows that it was an essential part of the eighteenthcentury British health regimen. The concept of 'insensible perspiration', first popularised by Sanctorius in the early seventeenth century, convinced physicians that the control of sweating - encouraging and discouraging it as appropriate - was vital to the maintenance of health. Accordingly, 'experiments on thickness, texture, colour and hygroscopic and insulating properties of materials formed a basis for an emerging theory of dress' (p. 94). While the medical profession defended traditional English wool flannel for its insulating properties, the public increasingly embraced new, lighter and more comfortable cotton and linen offerings. In his discussion of 'friction between the flannelists and the fashionable', Jankovic illuminates the fascinating and unexpected convergence of fashion, medical theory and the economics of textiles (p. 106).

In his final chapter ('The Choice of Airs'), Jankovic explores the rise and fall of health travel. Although Edenic images of the Mediterranean made such travel popular during most of the eighteenth century, criticism of the practice increased by the 1830s as medical experts sought more than just anecdotal evidence before recommending it to their patients. Jankovic shows how two factors - the release of health data on the British Navy and changing views on the aetiology of consumption - seemed to contradict long-held assumptions about the salubrity of warm, mild climates. Jankovic shows that the ensuing debate was less about the healthfulness of the Mediterranean than about 'the proper place of science in medical travel and professional credentials' (p. 142).

Jankovic has painted a lively and fascinating picture of a 'society on the defensive' (p. 154) against a wide range of aerial threats. Importantly, he reminds us that the quality of air was a luxury that only privileged classes could afford to contemplate. For most of the year, the poor faced the daily challenge of simply staying warm. But among the better-off, it was the "manufactured propriety and the ritual care of material accoutrements in indoor space by middle-class households that made cleaning, airing, heating, ironing, bleaching and dusting necessary ingredients of a decent life and - by degrees - the social origins of modern notions of a healthy environment' (p. 153).

Mariel Wolfson

Harvard University

Lars Ole Andersen, F $\phi$ r placeboeffekten. Indbildningskraftens virkning i 1800-tallets medicin (København: Museum Tusculanums Forlag, 2011), pp. 249, \$43/€ 34, illus, paperback, ISBN: 978-8-7635-2590-9.

In 1801, after having performed several trials on the medical treatment Perkins' tractors and fictitious tractors, the British physician John Haygarth (1740-1827) concluded that 